\title{
Single Cell Forces after Electroporation
}

Philip M. Graybill ${ }^{\dagger}$, Aniket Jana ${ }^{\dagger}$, Rakesh K. Kapania ${ }^{\oint}$, Amrinder S. Nain ${ }^{\dagger *}$, Rafael V. Davalos $\$ * *$

${ }^{\dagger}$ Department of Mechanical Engineering, Virginia Tech, Blacksburg, VA 24061, USA.

* School of Biomedical Engineering and Sciences, Virginia Tech-Wake Forest University, Blacksburg, VA 24061, USA

$\oint$ Department of Aerospace and Ocean Engineering, Virginia Tech, Blacksburg, VA 24061, USA

SUPPLMENTAL INFORMATION

Table S1. Sample size of cells analyzed for force response and percent of cells showing a biphasic stage of their response.

\begin{tabular}{|c|c|c|c|c|c|c|c|c|c|}
\hline \multirow[t]{2}{*}{ Condition } & \multicolumn{3}{|c|}{$\begin{array}{l}\text { Number of cells analyzed per } \\
\text { independent experiment }\end{array}$} & \multicolumn{3}{|c|}{$\begin{array}{c}\text { Number of cells with biphasic } \\
\text { stage }\end{array}$} & \multirow{2}{*}{$\begin{array}{l}\text { Total cells } \\
\text { with } \\
\text { biphasic } \\
\text { stage }\end{array}$} & \multirow[t]{2}{*}{$\begin{array}{c}\text { Total Cells } \\
\text { Analyzed }\end{array}$} & \multirow{2}{*}{$\begin{array}{c}\text { Total \% } \\
\text { of cells } \\
\text { showing } \\
\text { biphasic } \\
\text { stage }\end{array}$} \\
\hline & Exp1 & Exp2 & Exp3 & Exp1 & Exp2 & Exp3 & & & \\
\hline $500 \mathrm{~V} \|$ & 6 & 6 & 9 & 5 & 2 & 4 & 11 & 21 & $52 \%$ \\
\hline $1000 \mathrm{~V} \|$ & 9 & 6 & 11 & 6 & 6 & 8 & 20 & 26 & $77 \%$ \\
\hline $1500 \mathrm{~V} \|$ & 9 & 11 & 8 & 7 & 8 & 4 & 19 & 28 & $68 \%$ \\
\hline $500 \mathrm{~V} \perp$ & 7 & 7 & 9 & 0 & 0 & 0 & 0 & 23 & $0 \%$ \\
\hline $1000 \mathrm{~V} \perp$ & 8 & 6 & 8 & 5 & 2 & 1 & 8 & 22 & $36 \%$ \\
\hline $1500 \mathrm{~V} \perp$ & $0^{*}$ & $0^{*}$ & 4 & 0 & 0 & 3 & 3 & 4 & $75 \%$ \\
\hline
\end{tabular}


Table S2. Sample size of cells analyzed for viability response and percent cell death for each experiment.

\begin{tabular}{|c|c|c|c|c|c|c|c|c|c|}
\hline \multirow[t]{2}{*}{ Condition } & \multicolumn{7}{|c|}{$\begin{array}{l}\text { Ratio of dead cells to live cells } \\
(\% \text { cell death })\end{array}$} & \multirow{2}{*}{$\begin{array}{l}\text { Total Cells } \\
\text { analyzed }\end{array}$} & \multirow{2}{*}{$\begin{array}{l}\text { Percent } \\
\text { cell death }\end{array}$} \\
\hline & Exp1 & Exp2 & Exp3 & Exp4 & Exp5 & Exp6 & Exp 7 & & \\
\hline $500 \mathrm{~V} \|$ & $\begin{array}{l}0: 66 \\
(0 \%)\end{array}$ & $\begin{array}{l}0: 55 \\
(0 \%)\end{array}$ & $\begin{array}{l}0: 112 \\
(0 \%)\end{array}$ & - & - & - & - & 233 & $0 \pm 0 \%$ \\
\hline $500 \mathrm{~V} \perp$ & $\begin{array}{l}0: 68 \\
(0 \%)\end{array}$ & $\begin{array}{l}0: 25 \\
(0 \%)\end{array}$ & $\begin{array}{l}0: 37 \\
(0 \%)\end{array}$ & $\begin{array}{l}0: 26 \\
(0 \%)\end{array}$ & $\begin{array}{l}0: 25 \\
(0 \%)\end{array}$ & $\begin{array}{lll}- & - \\
\end{array}$ & $\begin{array}{l}- \\
-\end{array}$ & 181 & $0 \pm 0 \%$ \\
\hline $\begin{array}{l}500 \mathrm{~V} 2 \mathrm{D} \\
\text { Flat }\end{array}$ & $\begin{array}{l}0: 34 \\
(0 \%)\end{array}$ & $\begin{array}{l}0: 26 \\
(0 \%)\end{array}$ & $\begin{array}{l}0: 32 \\
(0 \%)\end{array}$ & $\begin{array}{l}0: 103 \\
(0 \%)\end{array}$ & - & - & - & 195 & $0 \pm 0 \%$ \\
\hline $1000 \mathrm{~V} \|$ & $\begin{array}{l}11: 49 \\
(18 \%)\end{array}$ & $\begin{array}{l}2: 60 \\
(3 \%)\end{array}$ & $\begin{array}{c}6: 54 \\
(10 \%)\end{array}$ & $\begin{array}{l}0: 33 \\
(0 \%)\end{array}$ & $\begin{array}{l}0: 27 \\
(0 \%)\end{array}$ & $\begin{array}{l}4: 44 \\
(8 \%)\end{array}$ & $\begin{array}{l}13: 113 \\
(10 \%)\end{array}$ & 416 & $7 \pm 2 \%$ \\
\hline $1000 \mathrm{~V} \perp$ & $\begin{array}{l}13: 26 \\
(33 \%)\end{array}$ & $\begin{array}{l}11: 34 \\
(24 \%)\end{array}$ & $\begin{array}{l}28: 65 \\
(30 \%)\end{array}$ & $\begin{array}{l}1: 20 \\
(5 \%)\end{array}$ & - & - & $\begin{array}{lll}- & - \\
\end{array}$ & 198 & $23 \pm 6 \%$ \\
\hline $\begin{array}{l}1000 \mathrm{~V} 2 \mathrm{D} \\
\text { Flat }\end{array}$ & $\begin{array}{l}0: 37 \\
(0 \%)\end{array}$ & $\begin{array}{c}4: 19 \\
(17 \%)\end{array}$ & $\begin{array}{c}8: 34 \\
(19 \%)\end{array}$ & - & - & - & - & 102 & $12 \pm 5 \%$ \\
\hline $1500 \mathrm{~V} \|$ & $\begin{array}{c}63: 38 \\
(62 \%)\end{array}$ & $\begin{array}{c}18: 47 \\
(28 \%)\end{array}$ & $\begin{array}{c}34: 37 \\
(48 \%)\end{array}$ & - & - & - & - & 237 & $46 \pm 10 \%$ \\
\hline $1500 \mathrm{~V} \perp$ & $\begin{array}{c}33: 0 \\
(100 \%)\end{array}$ & $\begin{array}{c}72: 2 \\
(97 \%)\end{array}$ & $\begin{array}{c}194: 7 \\
(97 \%)\end{array}$ & - & - & - & $\begin{array}{ll}- \\
-\end{array}$ & 308 & $98 \pm 1 \%$ \\
\hline $\begin{array}{l}1500 \mathrm{~V} 2 \mathrm{D} \\
\text { Flat }\end{array}$ & $\begin{array}{c}13: 2 \\
(87 \%)\end{array}$ & $\begin{array}{l}14: 10 \\
(58 \%)\end{array}$ & $\begin{array}{c}15: 5 \\
(75 \%)\end{array}$ & $\begin{array}{l}66: 27 \\
(71 \%)\end{array}$ & $\begin{array}{c}46: 2 \\
(96 \%)\end{array}$ & $\begin{array}{l}102: 24 \\
(81 \%)\end{array}$ & - & 326 & $78 \pm 5 \%$ \\
\hline
\end{tabular}

Table S3. Mechanical properties of polystyrene fibers for force calculation.

\begin{tabular}{lc}
\hline Property & Value \\
\hline Length $(\mu \mathrm{m})$ & 275 \\
Diameter $(\mathrm{nm})$ & 250 \\
${\text { Young's Modulus }(\mathrm{GPa}){ }^{1}}$ & 0.97 \\
Pre-Tension $(\mathrm{nN})^{1}$ & 201.2 \\
\hline
\end{tabular}


Table S4. Parameters for induced transmembrane potential (ITP) COMSOL model.

\begin{tabular}{lccc}
\hline Parameter & Symbol & Value & Reference \\
\hline Extracellular media conductivity & $\boldsymbol{\sigma}_{\mathbf{e}}\left(\mathbf{S} \cdot \mathbf{m}^{-\mathbf{1}}\right)$ & 1.28 & Measured \\
Extracellular media relative permittivity & $\boldsymbol{\varepsilon}_{\boldsymbol{e}}$ & 80 & 2,3 \\
Cytoplasm conductivity & $\boldsymbol{\sigma}_{\boldsymbol{c}}\left(\mathbf{S} \cdot \mathbf{m}^{-\mathbf{1}}\right)$ & 0.5 & 3 \\
Cytoplasm relative permittivity & $\boldsymbol{\varepsilon}_{\boldsymbol{c}}$ & 60 & 3 \\
Cell membrane conductivity & $\boldsymbol{\sigma}_{\boldsymbol{m}}\left(\mathbf{S} \cdot \mathbf{m}^{-\mathbf{1}}\right)$ & $3 \mathrm{e}-7$ & 3,5 \\
Cell membrane relative permittivity & $\boldsymbol{\varepsilon}_{\boldsymbol{c m}}$ & 8.57 & 3 \\
Cell membrane thickness & $\boldsymbol{d}_{\boldsymbol{m}}(\mathbf{n m})$ & 5 \\
\hline
\end{tabular}


a

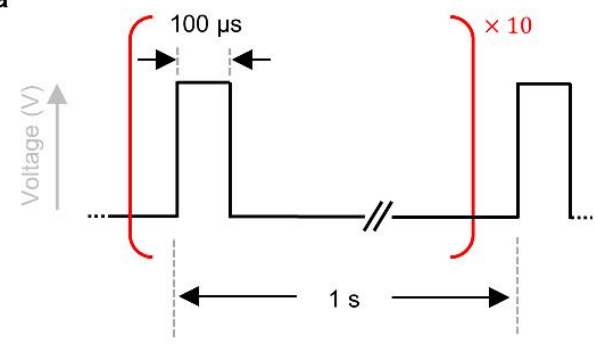

c
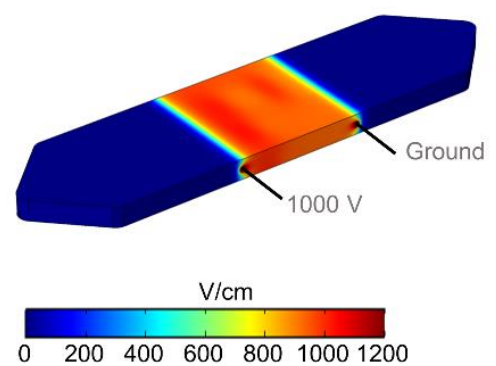

e
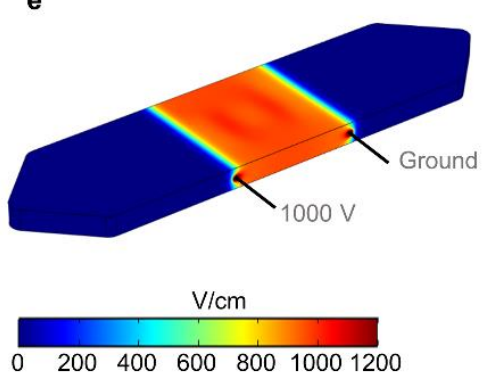

g

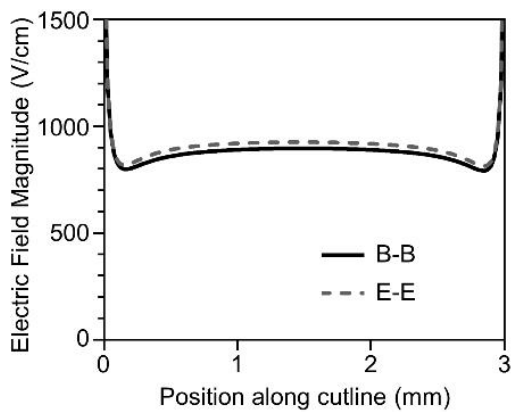

h

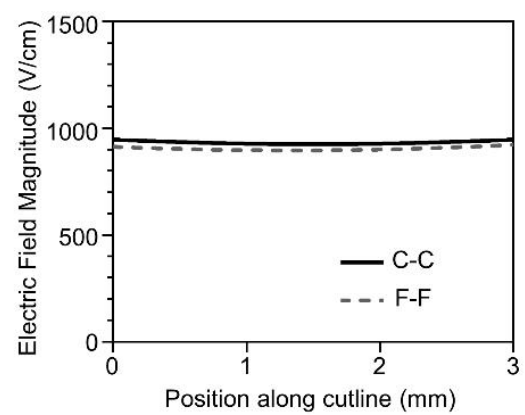

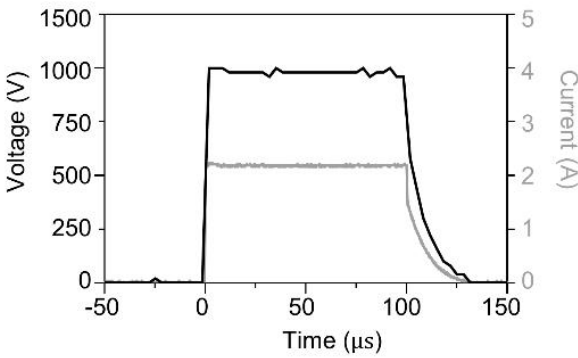

d
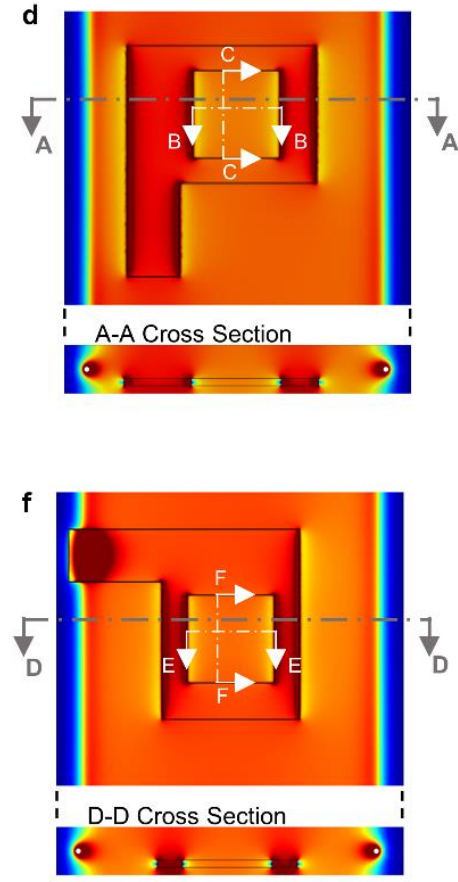

i

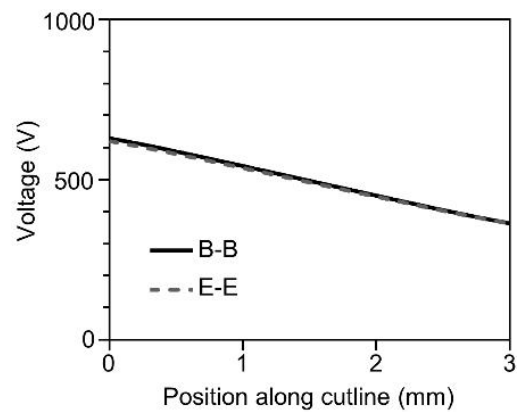

Figure S1. Electroporation waveforms and the electric field within the device. a) Cells were treated with ten, $100 \mu$ s square wave pulses at $1 \mathrm{~Hz}$. b) Actual voltage and current waveforms measured during the first pulse. Pulses approximate idealized square waves. c) A finite element model shows 
the electric field distribution along the walls of the fluidic channel $(\mathrm{c}, \mathrm{e})$ and in the plane of the nanofiber scaffold (d,f). In c) and d) the scaffold is modelled in the parallel orientation while e) and f) are modelled with the scaffold in the perpendicular orientation. The nanofiber region within the scaffold has an approximately uniform electric across the center of the scaffold. g) Along the cutlines B-B and E-E the electric field magnitude is mostly constant, with asymptotic regions near the edges. h) Along cutlines C-C and F-F, electric field is quite uniform. i) The voltage drop is nearly linear along cutlines B-B and E-E. The generated electric fields over the region of interest were approximately $441 \mathrm{~V} \mathrm{~cm}^{-1}, 882 \mathrm{~V} \mathrm{~cm}^{-1}$, and $1323 \mathrm{~V} \mathrm{~cm}^{-1}$ respectively across the scaffold region in the parallel orientation and $455 \mathrm{~V} \mathrm{~cm}^{-1}, 911 \mathrm{~V} \mathrm{~cm}^{-1}$, and $1366 \mathrm{~V} \mathrm{~cm}^{-1}$ respectively across the scaffold region in the perpendicular orientation. 
a

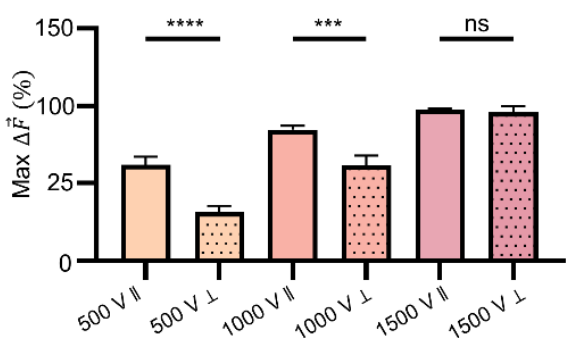

C

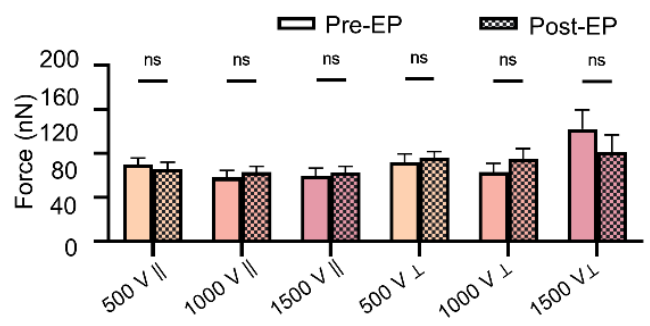

。
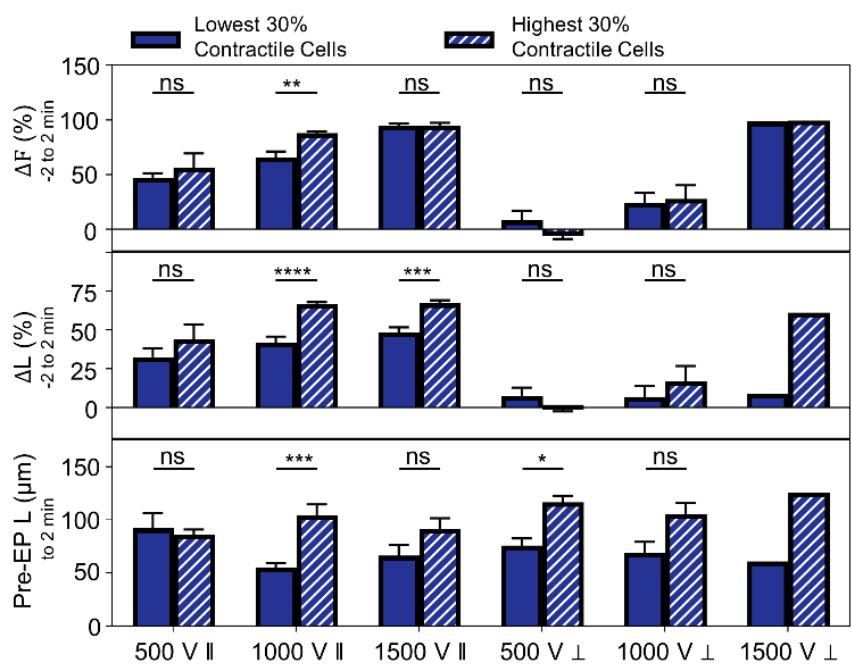

b

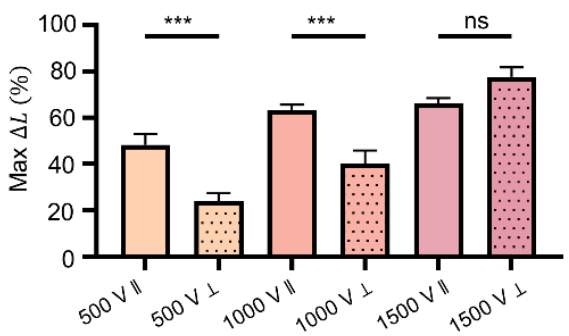

d

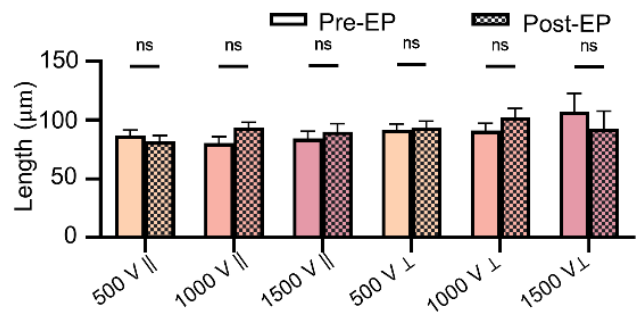

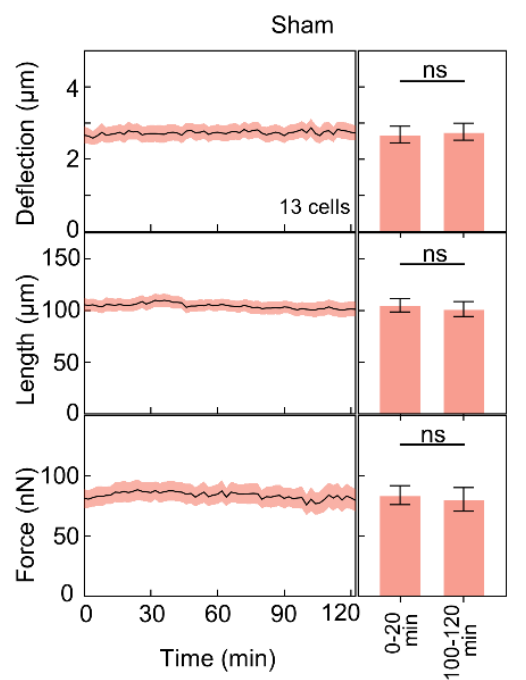

Figure S2. Force and length changes after electroporation. a-b) Data from Figure 2e-f, re-ordered to show significant differences due to electric field orientation. c-d) Cells post-electroporation do not show significant differences in contractile force or length compared to pre-electroporation values. Post-electroporation data collected at $180 \mathrm{~min}$ for $500 \mathrm{~V}$ and $240 \mathrm{~min}$ for $1000 \mathrm{~V}$ and 1500 V. e) For a given voltage and field orientation, high and low contractile cells show a similar force response in the first two minutes after EP. In the parallel orientation, the high contractile cells show a larger decrease in cell length immediately after electroporation when compared with low 
contractile cells, suggesting that contractility might increase the rate of rounding. However, high contractile cells also tend to also have longer initial lengths, so the rate of rounding may be dependent on both cell contractility and cell length. Stats not available for $1500 \mathrm{~V} \perp$ ( $\mathrm{n}=1$ for both bars). f) Response of control cells ('sham exposure') kept at the same culture conditions as electroporation experiments. Over the course of 2 hours cells, demonstrated steady-state levels of contractility and maintained consistent cell shapes. EP, electroporation. 


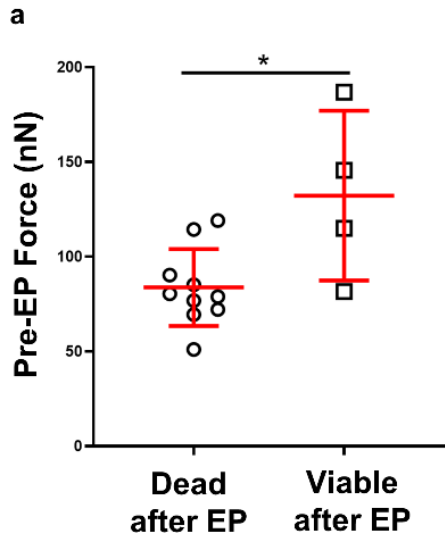

C

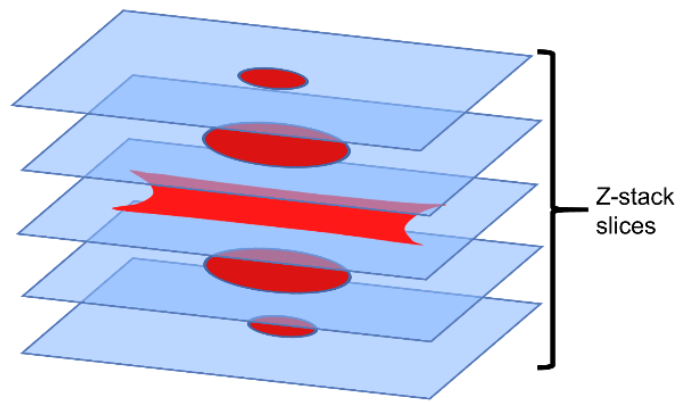

Cell volume $=\Sigma[($ Cell projected area in each slice $) \times(z$-slice thickness)]

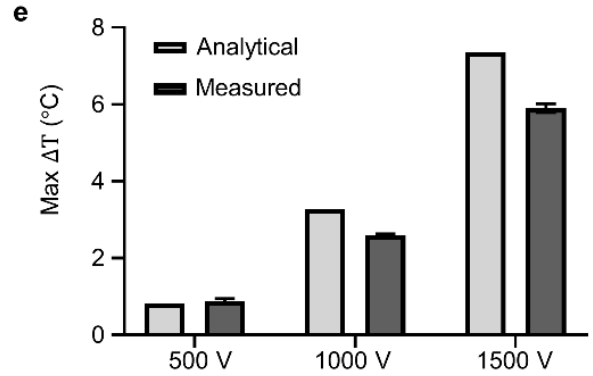

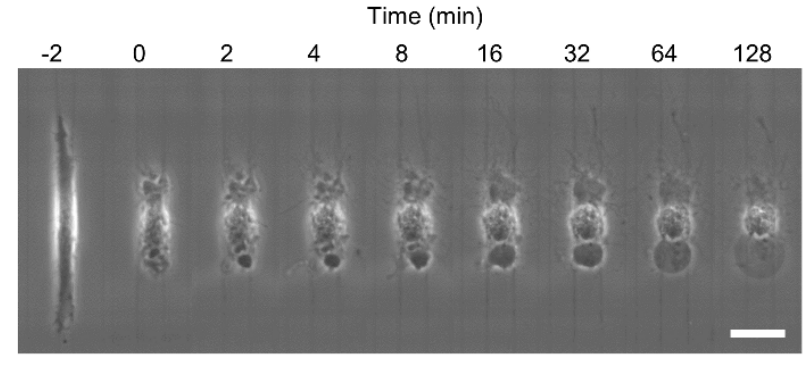

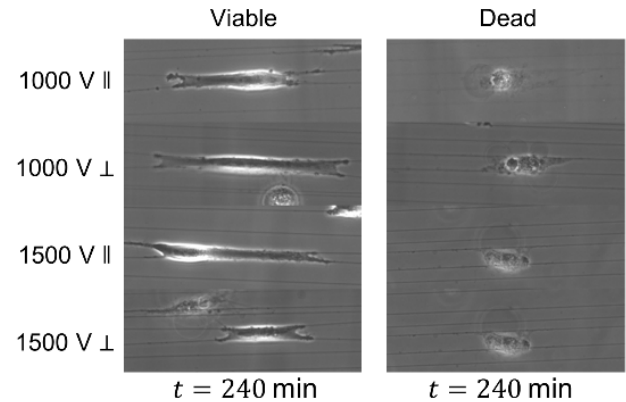

d
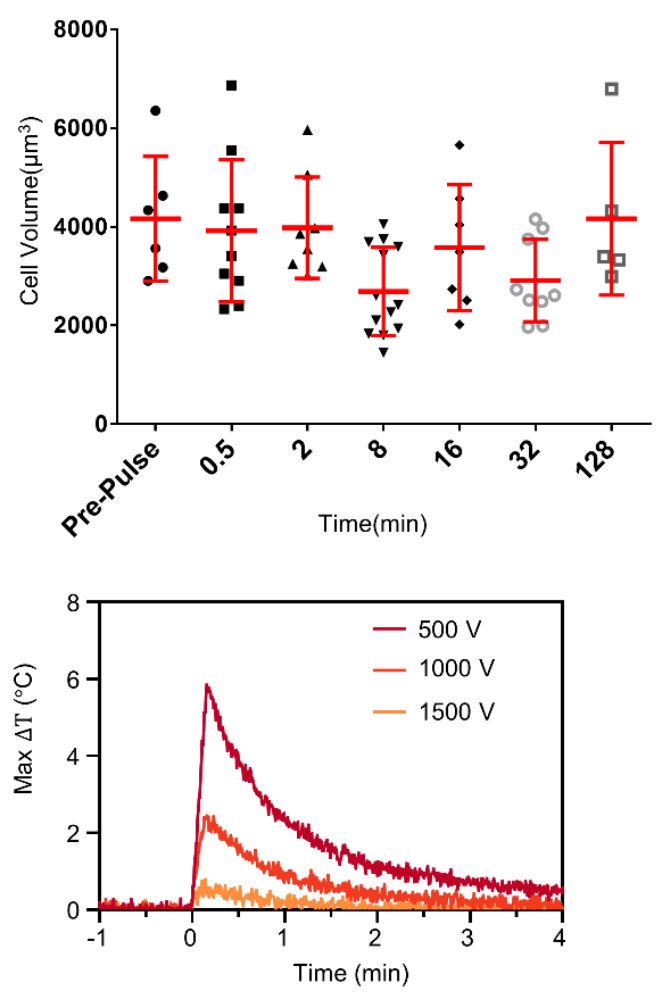

Figure S3. Additional analysis of cell death, cell volume, and Joule heating. a) Comparison of pre-electroporation forces for cells treated at $1500 \mathrm{~V}$ in the perpendicular orientation. The few cells that survived electroporation at $1500 \mathrm{~V}$ in the perpendicular orientation showed higher pre- 
electroporation forces than cells that did not survive electroporation b) This image panel shows an example of cell death by accidental cell death. Very soon after electroporation, the cell takes on visual signs of cell death such as a loss of contrast and large membrane blebs. Additionally, the cell rapidly losses contractility as shown by the lack of fiber deflection after electroporation. Scale bar $25 \mu \mathrm{m}$. c-d) Cell volume change during cell recovery. Volume was calculated in MATLAB using z-stacks of fluorescent images (stained for actin, microtubules, and the nucleus) of fixed cells. The 2D area of the cell in each slice was used to estimate cell volume. d) Cell volume seems to decrease after electroporation $(1000 \mathrm{~V} \|)$, with the greatest decrease between 8 and 32 minutes after electroporation. However, cell volume is not statistically significant between timepoints (ANOVA, $\alpha=0.05)$. $(\mathrm{n}=6,10,8,13,7,9$ and 5 corresponding to pre-pulse, $0.5,2,8,16$, and 32 minute timepoints respectively) e-f) Joule heating due to the electric pulses results in a rapid increase in temperature that returns to near pre-electroporation levels within minutes. The maximum temperature increase within the device due to Joule heating was experimentally and analytically verified to be under $8{ }^{\circ} \mathrm{C}$ for all conditions. Experimental measurements of Joule heating within the device was measured via a fiber optic temperature probe placed through the PDMS sidewall into the center of the electrode regions. f) The maximum temperature occurs immediately after pulsing and then returns to near pre-electroporation levels within 5 minutes. Fiber optic data collected at room temperature. 


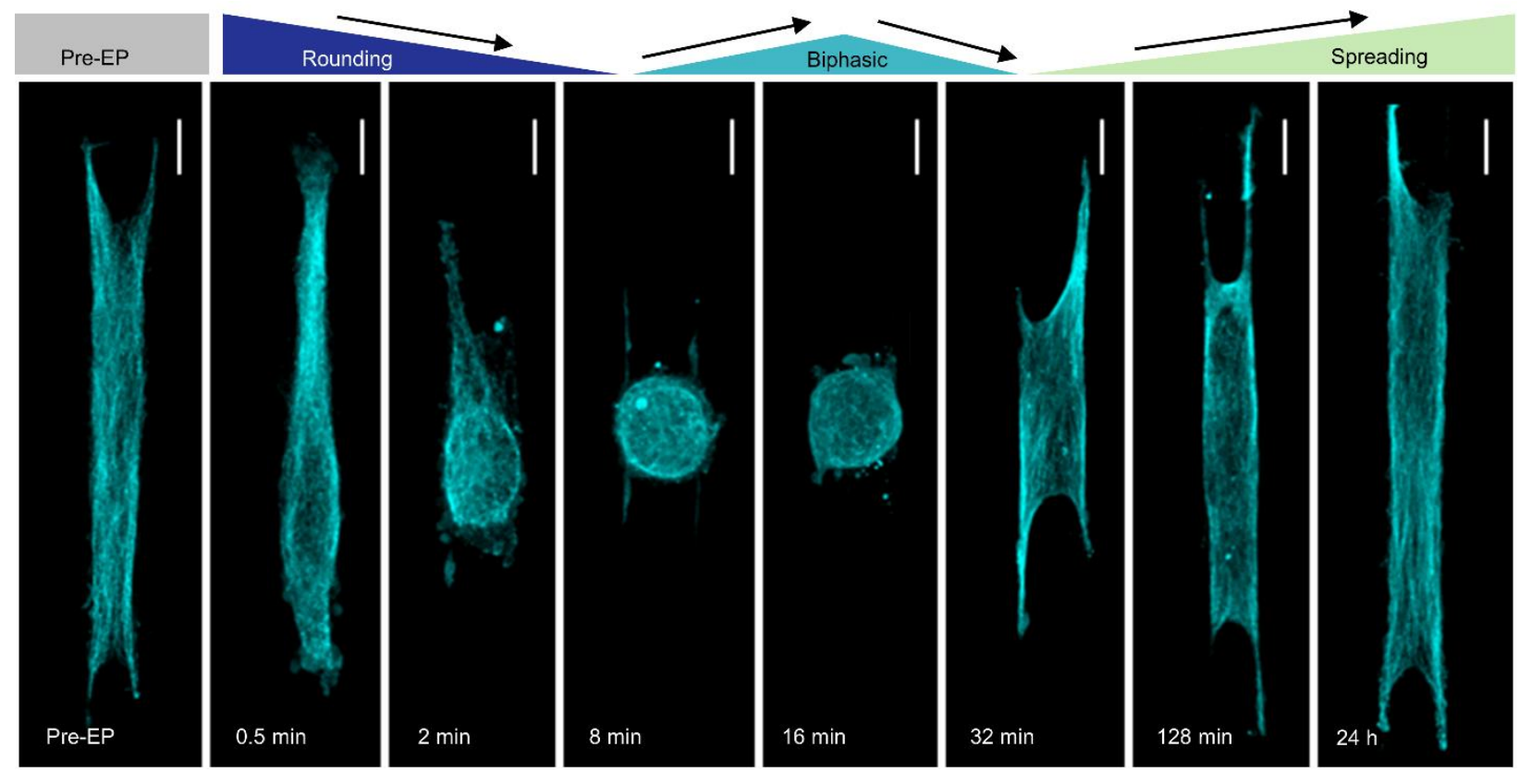

Figure S4. Microtubule dynamics after electroporation. a) Maximum intensity projections of cells stained for microtubules before electroporation and during various stages of recovery postelectroporation $(1000 \mathrm{~V}$ Electroporated cells $(1000 \mathrm{~V} \|)$ show a loss of microtubule alignment as the cells round, localization of tubulin at membrane blebs, and an eventual recovery of structure within 2 hours. Scales bars $10 \mu \mathrm{m}$. 


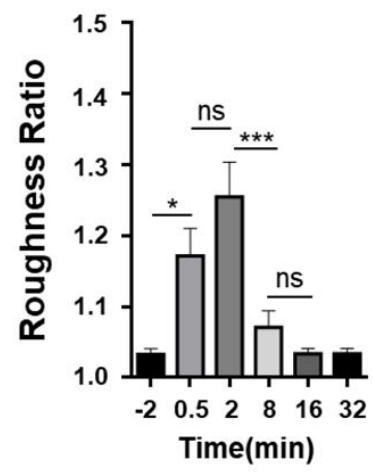

b
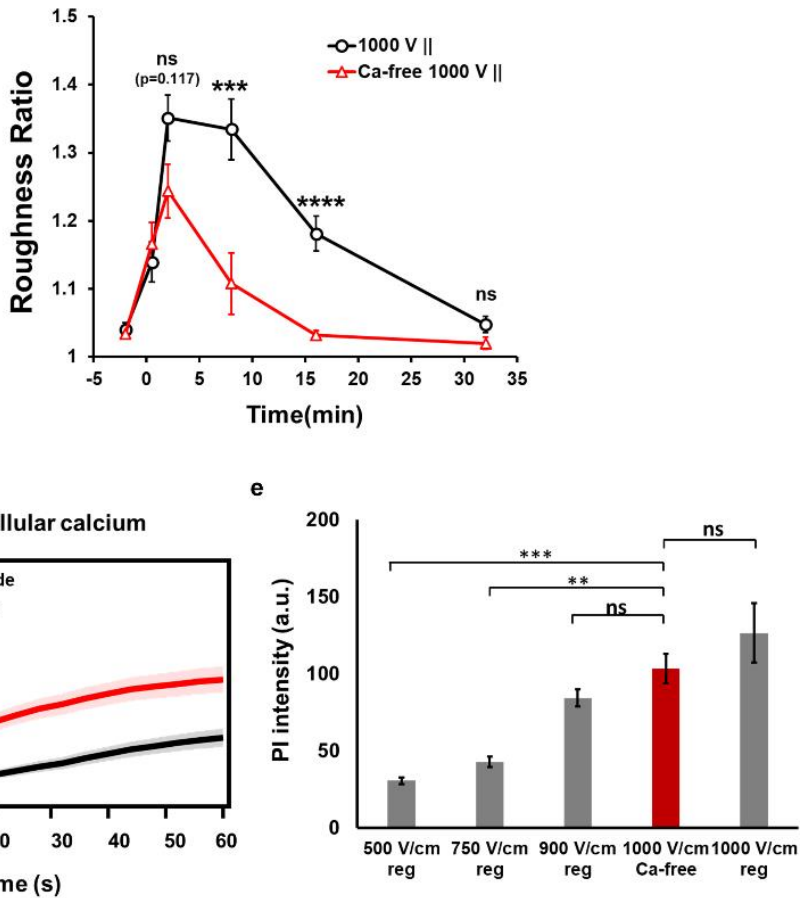

c

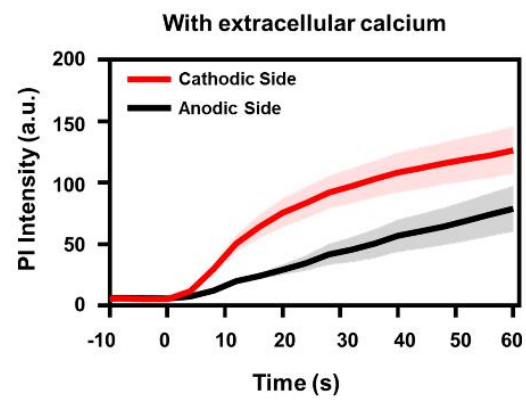

d

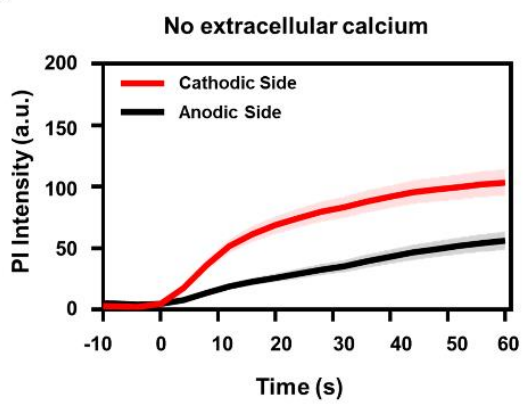

DMEM (with Calcium)

Calcium-free DMEM

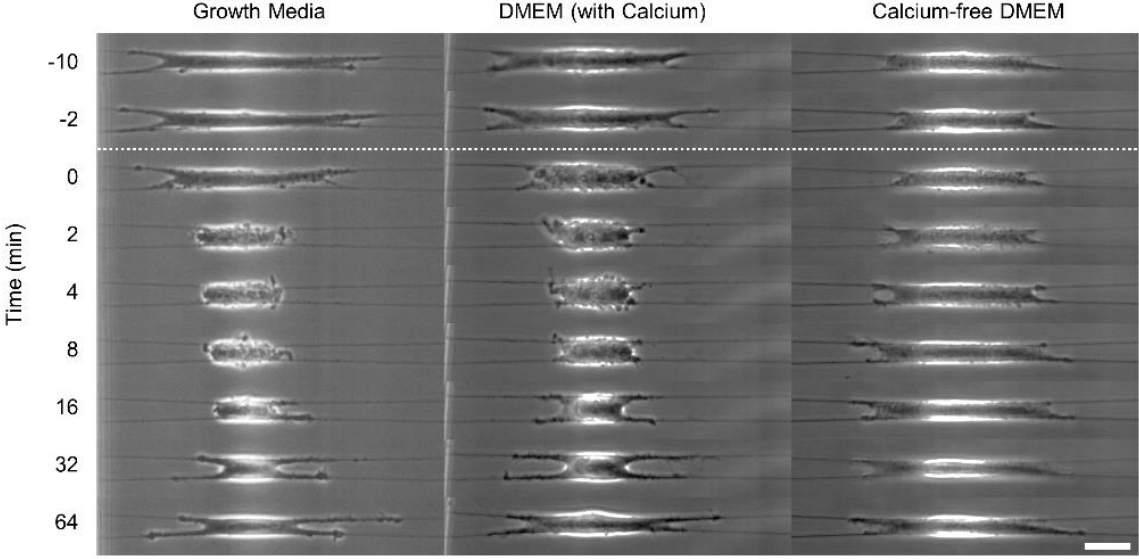

Figure S5. Analysis of blebbing, dye uptake, and cell rounding in calcium-free media. a) Temporal dynamics of cell blebbing in $\mathrm{Ca}$-free media ( $\mathrm{n}=10$ for each timepoint). The roughness ratio is defined in Figure 4f. b) Comparison of the blebbing dynamics after electroporation in regular media versus Ca-free media. c,d) PI uptake after electroporation at $1000 \mathrm{~V}$ (parallel orientation) in c) growth media $(1.95 \mathrm{mM}$ calcium, $n=18(\mathrm{~N}=4))$ and d) Calcium-free DMEM $(\mathrm{n}=19(\mathrm{~N}=4))$. PI uptake dynamics were recorded every 4 seconds with a 20x 0.8 NA objective. e) Comparison of 
PI uptake $60 \mathrm{~s}$ after electroporation at $500 \mathrm{~V}, 750 \mathrm{~V}, 900 \mathrm{~V}$, and $1000 \mathrm{~V}$ in regular media $(\mathrm{n}=$ $14(\mathrm{~N}=2), 12(\mathrm{~N}=2), 18(\mathrm{~N}=2), 18(\mathrm{~N}=4)$ respectively $)$ and at $1000 \mathrm{~V}$ in calcium-free DMEM $(\mathrm{n}=19$ $(\mathrm{N}=4)$. All experiments were conducted with cells in the parallel orientation. f) A representative cell electroporated at $1000 \mathrm{~V} \|$ in growth media $(1.95 \mathrm{mM} \mathrm{Ca}$; DMEM $+10 \% \mathrm{FBS}+1 \%$ PS), DMEM (1.8 mM Ca), and Calcium-free DMEM ( 0 mM Ca). Scale bar $25 \mu \mathrm{m}$.
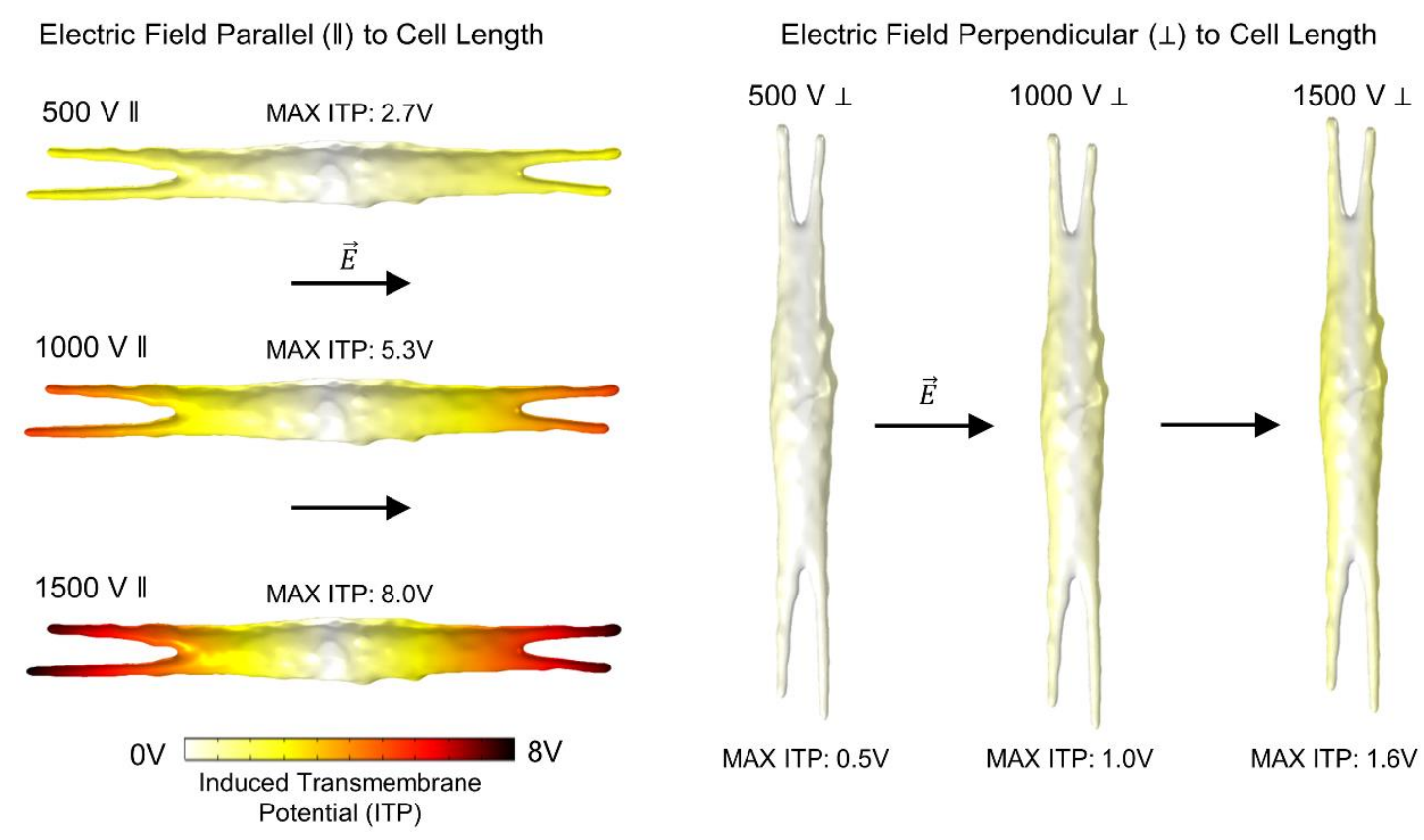

Figure S6. Induced transmembrane potential (ITP) model of a 3D cell in two orientations. A steady-state computational model of the induced transmembrane potential (ITP) of reconstructed cells indicates differences in the spatial distribution and magnitude of ITP. Cells elongated parallel to the field show high ITP values distributed around the protrusions of the cell. ITP is defined as the voltage difference across the cell membrane at the moment prior to pore formation. Conversely, cells elongated perpendicularly to the field show lower ITP levels that are distributed around the sidewalls of the cell. 


\section{Supplemental References}

1. Sheets, K.; Wang, J.; Zhao, W.; Kapania, R.; Nain, A. S., Nanonet Force Microscopy for Measuring Cell Forces. Biophys J 2016, 111, 197-207.

2. Kotnik, T.; Miklavčič, D.; Slivnik, T., Time Course of Transmembrane Voltage Induced by Time-Varying Electric Fields-A Method for Theoretical Analysis and Its Application. Bioelectrochem Bioenerg. 1998, 45, 3-16.

3. Murovec, T.; Sweeney, D. C.; Latouche, E.; Davalos, R. V.; Brosseau, C., Modeling of Transmembrane Potential in Realistic Multicellular Structures before Electroporation. Biophys $J$ 2016, 111, 2286-2295.

4. Hu, Q.; Joshi, R.; Beskok, A., Model Study of Electroporation Effects on the Dielectrophoretic Response of Spheroidal Cells. Journal of Applied Physics 2009, 106, 024701.

5. Sano, M. B.; Arena, C. B.; DeWitt, M. R.; Saur, D.; Davalos, R. V., in-Vitro Bipolar Nanoand Microsecond Electro-Pulse Bursts for Irreversible Electroporation Therapies. Bioelectrochemistry 2014, 100, 69-79. 